\title{
Sobre sincretismo e pureza. Uma perspectiva do candomblé angola
}

\author{
Ari Lima (UNEB)* \\ https://orcid.org/0000.0001.5557.6160
}

\section{Resumo:}

Este artigo é uma reflexão de um intelectual negro, mas também a reflexão de um negro intelectual, iniciado em um candomblé angola sobre as questões da pureza e do sincretismo no âmbito do candomblé baiano. Dessa forma, pretende-se convocar a atenção para uma perspectiva de compreensão e de prática do candomblé e do pensamento acadêmico quando se é de dentro estando fora ou quando se é de fora estando dentro. A discussão proposta tem como referência alguns autores e obras clássicos assim como outros contemporâneos. Do mesmo modo, considera a experiência do próprio autor como iniciado no candomblé de nação Angolão Paquetan Malembá.

Palavras-chave: Pureza. Sincretismo. Candomblé. Angola. Bahia.

\section{Abstract:}

\section{About syncretism and purity. An angolan candomblé perspective}

This article is a reflection of a black intellectual, but also the reflection of a intellectual black, initiated in an Angolan candomblé on the issues of purity and syncretism within the scope of Bahian candomblé. In this way, it is intended to call attention to a perspective of understanding and practice of candomblé and academic thinking when one is from the inside while being outside or when one is from the outside being inside. The proposed discussion has as reference some authors and classic works as well as other contemporaries. Likewise, he considers the author's own experience as initiated in the Angolão Paquetan Malembá candomblé nation.

Keywords: Purity. Syncretism. Candomblé. Angola. Bahia.

Todos nós, curiosos, observadores, pesquisadores e iniciados, sabemos ou deveríamos saber que é incerto o momento preciso em que teve início, no Brasil, o culto de divindades e ancestrais africanos. Logo, apesar do paciente e importante trabalho realizado por vários autores no sentido de restabelecer os vínculos primeiros (BASTIDE, 1985; CASTILLO e PARÉS, 2007; CASTILLO, 2017; CARVALHO, 1987; DANTAS, 1982; FERRE-

* Doutor em Antropologia Social pela Universidade de Brasília (UnB). Prof. Titular Pleno da Universidade do Estado da Bahia (UNEB). Prof. Permanente do Programa de Pós-Graduação em Crítica Cultural da UNEB.E-mail: arivaldopituba@gmail.com 
TI, 1985; CAPONE, 2005; MOTT, 1992; PARÉS, 2007; REIS, 2008; REIS, 1988; SANTOS, 1995; SILVEIRA, 2006; SILVEIRA, 2010; SODRÉ, 1988; SOUZA, 1986) é ainda duvidoso o ponto inicial de constituição das tradições religiosas afro-brasileiras que conhecemos contemporaneamente, as quais a esta altura cultuam divindades africanas, mas também afro-brasileiras e afro-indígenas. Do mesmo modo, também não se sabe ao certo desde quando essas divindades passaram a ser cultuadas em espaços sagrados que exigiram a presença de um(a) líder espiritual, pai de santo ou mãe de santo, e de um grupo de fiéis orientados espiritualmente por esse(a) líder. Em todo caso, se sabe que, desde então, o pai ou mãe de santo e seus filhos estão incumbidos de zelar pela preservação material de um espaço sagrado, que passou a ser conhecido como roça ou terreiro de candomblé, e pela manutenção de rituais, transmissão de mitos de origens, valores e práticas que apontam para uma concepção do que seja o sagrado, do que sejam as divindades cultuadas e mesmo do que seja o humano que se relaciona e evoca o divino através de ritmos e canções, orações, comidas, objetos e práticas ritualísticas.

A Bahia foi tomada como uma referência no que diz respeito à constituição dessas tradições. Na Bahia, embora tenham sido o último grupo de africanos a chegar como escravos, os iorubás e sua tradição religiosa ketu foram reconhecidos, desde o século XIX (RODRIGUES, [1932]1988; CARNEIRO, 1948; BASTIDE, 2001), como modelo do que deveria ser a organização religiosa dessas tradições assim como a reatualização de realidades sociais, míticas e místicas concebidas originalmente no continente africano por etnias distintas, que cultuavam deuses distintos, embora concebessem o sagrado através de valores equivalentes. Do mesmo modo, normalmente, é à tradição ketu que se recorre quando o senso comum ou formadores de opinião pretendem identificar e descrever o que seja a presença e a herança africana na Bahia e no Brasil (CARNEIRO, [1948]2008; SODRÉ, 1988).

Nesse sentido, o artigo que ora apresento, pretende ser uma reflexão de um intelectual negro, mas também a reflexão de um negro intelectual (SANTOS, 2007), ${ }^{1}$ iniciado em um candomblé angola, sobre as questões da pureza e do sincretismo no âmbito do candomblé baiano. Dessa forma, pretende-se convocar a atenção para uma perspectiva de compreensão e prática do candomblé e do pensamento acadêmico quando se é de dentro estando fora ou quando se é de fora estando dentro (BRAGA, 2000). Tomo como referência alguns autores e obras clássicos assim como outros contemporâneos. Do mesmo modo, considero minha experiência como iniciado no candomblé de nação Angolão Paquetan Malembá. Por conseguinte, acredito que seja possível ampliar o conhecimento sobre o candomblé na Bahia, tomando como ponto de partida a memória oral dos continuadores da nação Angolão Paquetan Malembá, já descrita parcialmente em obra recente (ALVES, 2010). A propósito, em relação ao conceito de "nação religiosa", tomo como referência a perspectiva de Vivaldo da Costa Lima para quem os terreiros de Candomblé mantêm

[...] apesar dos mútuos empréstimos osten-

1 Sales Augusto dos Santos (2007, p. 226) define o "negro intelectual" como aquele intelectual ou pesquisador que porta "uma ética da convicção anti-racismo adquirida ou incorporada dos Movimentos Sociais Negros, bem como um ethos acadêmico-científico ativo, posicionado pró-igualdade racial e pró-políticas de promoção da igualdade racial; ethos este oriundo da interatividade daquela ética com uma ética acadêmicocientífica adquirida ou incorporada de cursos acadêmico-científicos". 
sivos e das influências perceptíveis no ritual como na linguagem, os padrões mais característicos e distintivos de suas culturas formadoras, como uma espécie de arquétipo da perdida totalidade ontológica original. Esses padrões dominantes são como a linha mestra num processo multilinear de evolução, aceitando ou rejeitando inovações, mas retendo sempre a marca reveladora de sua origem, em meio à integração e à mudança. [...] A 'nação', portanto, dos antigos africanos na Bahia foi aos poucos perdendo sua conotação política, para se transformar num conceito quase exclusivamente teológico. 'Nação' passou a ser, desse modo, o padrão ideológico e ritual dos terreiros de candomblé da Bahia, estes, sim, fundados por africanos angolas, congos, jejes, nagôs, sacerdotes iniciados de seus antigos cultos, que souberam dar aos grupos que formaram a norma dos ritos e o corpo doutrinário que se vêm transmitindo através dos tempos e da mudança nos tempos (LIMA, 1984, p.19-20).

Inicialmente, vou me recusar a definir e categorizar o candomblé como uma "religião de matriz africana". Ao invés disso, inspirado na experiência que tenho tido no Angolão Paquetan Malembá e na definição de Sidney Mintz e Richard Price (2003) para uma "cultura afro-americana", vou compreendê-lo aqui como uma religião de orientação africana. Ou seja, por um lado, acredito que essa religião se formou e permaneceu ao longo da história através do empenho de africanos e descendentes que, no Brasil, reconstituíram laços de parentesco, assim como rituais e mitos de deuses originalmente cultuados em África. Por outro lado, observo que essa religião, como tal, foi determinada por perspectivas históricas, sociais, econômicas e culturais definidas pela colonização portuguesa, por um longo período de escravidão negra e permanente hegemonia branca. Logo, é uma religião que remete à África, mas que não pôde prescin- dir da realidade histórica, social, econômica e cultural na qual se encontravam seus fundadores. Em suas variações no Brasil, essa religião tem agregado majoritariamente negros, mas também mestiços e brancos. Tem se constituído como uma reserva de memória, de relações e laços sociais supostamente africanos, mas também de memória, relações e laços gerados durante a colonização, a escravidão e o pós-escravidão, tal como o sincretismo cultural e religioso, a experiência da raça, do racismo e das desigualdades raciais (LIMA e ALVES, 2013).

Minha referência fundamental é o Nzo kwa Mutalombô ye Kaiongo (Terreiro de Mutalombô e Kaiongo), localizado em Cajazeiras XI, Salvador, liderado pelo pai de santo Jorge Barreto dos Santos, também conhecido como Tata kwa nkisi Mutá Imê. Frequento esse terreiro desde o ano de 2010 e lá fui iniciado como mona de nkisi no ano de 2015. É nesse terreiro e, sobretudo, através desse pai de santo citado, que tenho aprendido e experimentado a realidade e a tradição do candomblé Angolão Paquetan Malembá. Conceitualmente, tomo a tradição no viés do historiador Eric Hobsbawn (1984), mas também no viés do historiador e "tradicionalista” Amadou Hampâté Bâ (1982). Para o primeiro, a tradição deve ser vista como "um conjunto de práticas, normalmente reguladas por regras tácita ou abertamente aceitas; tais práticas, de natureza ritual ou simbólica, visam inculcar certos valores e normas de comportamento através da repetição, o que implica, automaticamente, uma continuidade em relação ao passado (HOBSBAWN, 1984, p. 9)”. Tais práticas são sempre contextuais, ou seja, são reguladas pela agência de indivíduos e grupos sociais interessados pela ratificação de valores e normas de comportamento elaborados no tempo e no espaço. Isso quer dizer que as 
tradições são inventadas, que os valores e normas de comportamento que lhes correspondem em vez de naturais são um dado da história. Para o segundo,

[...] o testemunho, seja escrito ou oral, no fim não é mais que testemunho humano, e vale o que vale o homem. [...] o que se encontra por detrás do testemunho, portanto, é o próprio valor do homem que faz o testemunho, o valor da cadeia de transmissão da qual ele faz parte, a fidedignidade das memórias individual e coletiva e o valor atribuído à verdade em uma determinada sociedade. Em suma: a ligação entre o homem e a palavra. [...] Se formulássemos a seguinte pergunta a um verdadeiro tradicionalista africano: 'o que é tradição oral?', por certo ele se sentiria muito embaraçado. Talvez respondesse simplesmente, após longo silêncio: 'É o conhecimento total' (BÂ, 1982, p. 181; 182).

No contexto do Terreiro de Mutalombô e Kayongo, embora não seja proibido de anotar ou registrar falas e imagens, a intensa experiência e aprendizado tem ocorrido sobretudo através da escuta, da participação e performance em rituais e cerimônias sagradas. Ou seja, não sou negado como intelectual ou como negro intelectual, ou seja, alguém de fora, mas sou todo o tempo exigido como filho de santo, alguém de dentro, particularmente como muzenza, nome genérico atribuído àquele(a) que se encontra no primeiro estágio do processo de iniciação. Vale também acrescentar que tenho sido conduzido no sentido de reconhecer a legitimidade e importância da tradição ketu no que diz respeito à afirmação e proteção de uma memória africana e afro-baiana, porém tenho sido enfaticamente lembrado no que diz respeito à anterioridade da formação do candomblé angola em relação ao ketu, assim como no que diz respeito a uma inversão da acusação dos adeptos e estudiosos do candomblé ketu de que o angola teria copiado o modelo ketu e perdido sua "pureza" em contato com os segmentos brancos e mestiços da sociedade baiana.

Do mesmo modo, minha experiência aponta para uma tradição afro-brasileira eminentemente oral em que a escrita, por outro lado, nunca esteve completamente ausente. 0 estilo de narrativa que caracteriza os sujeitos falantes e, particularmente, o Tata Mutá Imê, implica na atenção a um ritmo de fala marcado pelo uso excessivo de pausas, reticências, assim como por performances que complementam ou substituem as palavras. Há também a recorrência discreta à memória escrita, à crença no poder de revelação e realização da palavra, logo no uso de uma linguagem poética que favorece a permanência em segredo de alguns conteúdos. Do mesmo modo, é recorrente o uso de um vocabulário incomum ou que tem seu significado usual alterado e em seguida produz significação subliminar, ancorada contextualmente. Neste sentido, tal como observa Julie Cavignac (1999), ao menos entre os antropólogos, faltam ferramentas precisas tanto do ponto de vista conceitual quanto metodológico no estudo de tais narrativas orais. Ou seja, a enunciação e escuta de tais narrativas apontam para dilemas analíticos que normalmente não se mostram óbvios para o pesquisador e exigem que a interpretação e análise nunca desconsiderem aspectos estruturais, experiências pessoais, temáticas, emoção e situações constitutivas das narrativas relacionadas às tradições orais.

É nesse contexto que verifico o retorno à antiga questão da "pureza" e do "sincretismo" mencionado em falas de praticantes do candomblé, nas pioneiras etnografias ou em estudos historiográficos, alguns deles já citados por mim aqui. Essas duas questões têm gerado pontos de abertura para a descrição e problematização da história social e 
da experiência cultural do candomblé, tanto quanto têm suscitado e firmado uma memória sobre as práticas afro-religiosas. Uma referência inevitável é o pioneiro Nina Rodigues ([1900] 2005), quando alertava para o fato de que o cristianismo teria falhado em relação à tentativa de correção do atraso espiritual dos negros, pois os catequisou apenas parcialmente. A "ilusão da catequese" teria sido uma artimanha dos africanos para manter a prática de seus cultos sagrados. 0 sincretismo, portanto, desde Nina Rodrigues, aparece como um aspecto pejorativo e permissivo na discussão acadêmica e na experiência do candomblé.

\section{A segunda catequese do candomblé baiano}

Esse aspecto pejorativo e essa lógica permissiva atribuída ao sincretismo contribuiram para que houvesse, segundo Bastide, "uma dupla falsificação de valores". Ao tratar das origens históricas do sincretismo a partir da ordem psicológica que lhe atribue e analisa, Bastide (1985) identifica um movimento cultural bastante significativo: em um pólo a influência a que o branco submeteu o escravo, e como reflexo, num outro pólo, a "adulteração" a que os negros submeteram os valores portugueses. Sob esta perspectiva, temos a sugestão de que a escravidão teria causado nos negros um "complexo de inferioridade", e o catolicismo, como religião das classes dominantes, teria se configurado como instrumento de elevação dos cultos africanos ou afro-brasileiros, através dos deslocamentos das denominações dos orixás ketu para seus equivalentes santos católicos, mais civilizados.

Considerando, portanto, as observações dos autores citados acima, temos então uma situação em que o sincretismo acaba por suscitar uma degeneração e um discurso sobre a degeneração da tradição africana do candomblé evidenciada desde o processo de assimilação e incorporação de elementos tradicionais de outras representações religiosas, particularmente do catolicismo (RAMOS, [1934]1988). Do mesmo modo, a ideia de uma pureza absoluta criada para legitimar a superioridade das nações de origem iorubá na Bahia gira quase que completamente em torno da lógica do sincretismo. Ou seja, aquelas casas de candomblé onde os cultos já tinham se deixado penetrar por influências externas, eram consideradas corrompidas, impuras e, desse modo, não poderiam ser reconhecidas como candomblés ou como africanas (BASTIDE, 1985, p. 392). Ou então, seriam paulatinamente reconhecidas como candomblé na medida em que cada vez mais se assemelhassem ao modelo forjado pelos adeptos ketu e seus estudiosos intérpretes (DANTAS, 1982). Enfim, como afirma Capone,

Para R. Bastide, se os banto são mais 'permeáveis às influências externas', eles são, em conseqüência, os mais atraídos pelo sincretismo, um sincretismo marcado pela acumulação de elementos heteróclitos. Trata-se, portanto, de um sincretismo mágico, e não religioso, caracterizado, na teoria bastidiana, pela lei das correspondências que fundamenta a noção de corte. Como já tinham feito, antes dele, Nina Rodrigues e Edison Carneiro, R. Bastide ligará os banto à magia e os ioruba à religião: 'Os Bantos na atividade de seus candomblés dão mais lugar à magia que os iorubas' (BASTIDE, 1971, p. 387). Bantos 'feiticeiros', mas também 'desafricanizados', porque a perda de suas tradições era o único meio de que dispunham para se elevarem em uma hierarquia 'de posições ou de status' que era também uma hierarquia 'étnica' (CAPONE, 2005, p.78-79).

De tal modo, fracassada a catequese católica, paulatinamente, se impôs um se- 
gundo esforço de catequese, agora negro e afro-brasileiro, conduzido por prepostos da nação ketu em relação às demais nações de candomblé. Dessa vez, o viés teológico cristão veio emoldurado e até fundamentado em valores, práticas, sujeitos e ações afro-orientados. A propósito, é oportuna a citação de um registro, feito pelo sociólogo Donald Pierson, nos anos 1930, sobre o modelo de candomblé implantado por Eugênia Ana dos Santos, a célebre mãe Aninha, fundadora e líder do Axé Opô Afonjá:

Esta mãe de santo tinha sido 'feita' havia mais de cinqüenta anos, no candomblé do Engenho Velho. Ela se gabou: 'Minha seita é nagô puro, como o Engenho Velho. Tenho ressuscitado grande parte da tradição africana que mesmo o Engenho Velho tinha esquecido. Têm uma cerimônia aí para os doze ministros de Xangô? Não! Mas eu tenho' (PIERSON, [1945] 1971, p. 319).

Luis Nicolau Parés destaca dois aspectos importantes nessa fala de mãe Aninha:

Primeiro, como foi apontado por Vivaldo da Costa Lima, a identificação do terreiro como pertencente à nação nagô deriva da afiliação religiosa de mãe Aninha a uma casa de culto nagô - o Engenho Velho, onde ela foi iniciada - e não de vínculos de parentesco biológico. É sabido que os pais de Aninha eram gruncis, um grupo étnico de Ghana, sem qualquer laço cultural ou histórico com a região iorubá. Portanto, pelo menos desde o início do século XX, os descendentes de africanos nascidos na Bahia podiam identificarse como nagôs em virtude de sua iniciação, independente da sua ancestralidade étnica. [...] Segundo, as palavras de Aninha estabelecem uma associação conceptual explícita entre a noção de 'pureza' e a tradição religiosa nagô, preservada na sua casa e no Engenho Velho - 'o candomblé mais antigo do Brasil', de acordo com a tradição oral. Neste comentário, estaria implícita uma oposição entre a pureza nagô e a impureza, a mistura ou o sincretismo de outras tradições. Toda- via, Aninha declara ter 'ressuscitado grande parte da tradição africana', que mesmo o Engenho Velho tinha esquecido, sugerindo maior proximidade da África e maior fidelidade a ela, o que redundaria em maior grau de 'tradicionalismo' e autenticidade (PARÉS, 2006, p. 300-301).

Nesse mesmo trabalho, Parés também argumenta e enfatiza que

[...] apesar do ecletismo criativo e do movimento de valores e práticas no percurso fronteiriço das nações ketu, jeje ou banto angola e congo, os rituais é que são tomados como sinais diacríticos. Esses rituais podem ser fronteiras reais, mas também imaginárias em relação a um passado africano ou tradição religiosa particular. Desse modo, a unidade básica de identidade coletiva e orgulho pode ser o próprio grupo de culto e até mesmo as congregações pertencentes à mesma nação, logo apesar de sua possível solidariedade e cooperação, não escapam a uma dinâmica competitiva(2006, p. 299-300).

\section{Enfim, afirma ainda Parés que}

Os especialistas em Candomblé têm, efetivamente, um agudo senso crítico para descriminar o que julgam 'certo', do que consideram 'errado', 'deturpado' ou 'misturado'. Este juízo se baseia, sobretudo, em aspectos formais da prática religiosa, mais do que em diferenças teológicas derivadas das suas crenças. Num mercado religioso competitivo, o que está sendo avaliado e julgado o tempo todo é a oportunidade e a eficácia da prática e, implicitamente, o conhecimento e o poder espiritual do seu agente. É a ordem estrutural e formal da praxis, o jeito como as coisas são feitas, o que vira motivo de crítica. Neste sentido, veiculadas através da 'fofoca informal', as disputas entre especialistas religiosos, a propósito de questões de ortodoxia ritual, constituem um dos principais territórios para estabelecer diferenças e identidades (PARÉS, 2006, p. 319, grifo nosso).

A propósito, em outro viés, meu principal interlocutor e mestre espiritual, o pai 
de santo Mutá Imê, com 63 anos de idade e de iniciação no candomblé angola ainda no ventre materno, relata e evidencia na sua trajetória religiosa, na referência "aos mais antigos", nas práticas e discursos daqueles que hoje compõem a nação à qual se filia Angolão Paquetan Malembá - assim como no próprio terreiro que lidera, a contingência da catequese ketu em rituais, linguagem, atitudes. Do mesmo modo, aponta para a repercussão desta catequese na maneira como se concebe o candomblé e se altera valores e ortodoxia teológica através da tendência à uniformização de todas as nações religiosas do candomblé baiano.

O Tata Mutá Imê me repetiu algumas vezes que a referência ketu e de suas práticas ritualísticas é uma orientação forte no modo como o candomblé tem sido praticado entre diversas nações e casas baianas, ao menos, nos últimos 40 anos. Entretanto, ele também chamou atenção para o fato de que, no passado, era possível perceber como também os rituais e referências de outras nações, em particular a angola, se colocavam como orientação para as práticas ketu.

Houve uma época que os caboclo invadiram os terreiros ketu e muitos não queriam aceitar porque achavam uma coisa muito ruim, muito pesada. Muitos pais de santo e mães de santo daquela época morreram por causa de caboclo. De forma que a maioria dos terreiros hoje ditos famosos eles não cultuam, não recebem caboclo, mas eles cultuam escondido, eles têm que saudar as matas, porque essas matas brasileiras não pertencem aos negros africanos e sim aos índios brasileiros. Então o caboclo vem, ele conversa, ele dá um passe, ele passa um ebó, um banho, aquela reunião é pra aliviar o sofrimento das pessoas. Quando os iorubanos resolvem aceitar caboclo, alguns deles, como eles não sabem, e muito orgulhosos, eles não pediam conhecimento, nem apoio dos bantos, então eles faziam de qualquer jeito. Eu entendo e muita gente en- tende que quando esses estudiosos falam dos candomblés de angola, nessa mistura de caboclo, na verdade não eram terreiros de candomblé de angola, eram terreiros de nação ketu que fazia festa de caboclo e não sabia fazer. Misturavam tudo, bebiam... E eu quero frisar que os candomblés bantos sabiam muito bem dividir o candomblé de nkisi (inquice) do candomblé de caboclo. Então quando se tinha festa de caboclo, era só festa de caboclo, não se cantava pra nkisi. Como hoje você vê aí o povo de ketu, porque eles não sabem fazer festa de candomblé de angola, não sabem fazer festa de caboclo. Aí hoje o que é que você vai ver? Aprenderam as rezas de nkisi dentro do angola, angola-congo, e pega essas rezas de quarto e leva pros caboclos. Reza pros caboclos como se tivesse rezando pra santo. Aí fica uma mistureba e eles ficavam dizendo que era festa de angola. (Depoimento concedido em 29 de janeiro de 2012, grifo nosso)

$\boldsymbol{P}$ - $O$ senhor acha que há uma coincidência ou os angola, os banto, se distinguem em visão de mundo, de humanidade e concepção teológica com os ketu?

$R$ - Eu acho importante não correlacionar angola e ketu, porque quando você correlaciona é uma forma ainda de manter esta hegemonia iorubana. Você coloca lá os nomes bakongo e as pessoas que se designem a buscar as suas correspondências. Eu na minha concepção vou tá falando da minha nação que é a nação que eu conheço. Quando eu falo assim Nzila... quem é Nzila pra mim? Qual a diferença de Nzila pra Exu? Quando eu tô falando de Nzila, eu tô falando de caminho, desta transformação evolutiva, desta relação que Nzila tem com os deuses, os nkisis, ligada aí ao cosmos à natureza, passando diretamente esta ligação com os nkisis... até mesmo porque esta questão é muito, muito original, porque nkisis, orixá, vodu, caboclo são cultuados de formas diferentes, são fundamentados com elementos diferentes, com línguas diferentes, com danças e cânticos e orações diferentes, não dá para correlacionar.

P - Mas tem aquela coisa, a gente vai numa mãe de santo ketu, ela diz você é filho de Yan- 
sã, a gente vai numa casa de angola aí ela diz você é filho de Kaiongo. Pra pessoa que recebe uma e outra resposta, ela faz uma associação, está havendo equivalência...

$R$ - É, mas aí o que eu vejo muito hoje, digamos aí, de uns 20, 25 anos pra cá, essa coisa se dá na medida em que o desrespeito foi criado entre as nações. Eu lembro quando garoto, as histórias que os mais velhos contavam e vi minha mãe se comportar desta forma. Quando ela jogava pra alguém, bem diferente disso que você tá falando, de um pai de santo iorubano e outro bakongo falar na sua língua a que energia predomina no seu eixo, antigamente se tinha o respeito. Ao invés de só ver isso, se via a que nação você pertencia, hoje não existe mais. Por que não existe mais? Exatamente por aquilo que falei antes. Você é ketu, eu gosto de você, tenho uma relação com você, um filho da minha casa gosta de você, participa das obrigações na sua casa e quando aquele filho que vou iniciar, eu convido você pra ser pai pequeno e aí você vem já trazendo já seus fundamentos, porque como ele é seu filho você tem de passar um pouco dos seus fundamentos pra ele. Essa coisa foi ficando muito forte e as pessoas foram aprendendo os fundamentos de nações diferenciadas e levando isso pro seu próprio terreiro. Naquela época, você não via um pai ou uma mãe de santo, um babalorixá, uma yalorixá, um tata, uma mameto negar a originalidade dos nkisi, orixá ou vodu. Se você chegasse na casa de um pai de santo ketu, se você chegasse na casa de um pai de santo angola, eles iam verificar a que nação você pertencia. Eles lhe diriam: "Olha meu filho, a sua nação é ketu você vai ter que procurar uma casa de ketu pra se iniciar, porque aqui nós somos angola, não sabemos, não podemos fazer o seu santo nessa casa. Então tinha essa ética, eu chamo isso de ética. Essa ética foi quebrada por conta disso tudo, por conta dessas relações interpessoais. Eu vejo assim, é uma questão minha, da minha nação, de relação com os meus mais velhos. A sua originalidade, ela só se permite navegar por aquela água... por mais que você aprenda a falar inglês, você jamais vai ser americano. Então por mais que seu santo seja iorubano iniciado no candomblé angola, ele jamais vai deixar de ser iorubano. (Depoimento concedido em $9 \mathrm{de}$ janeiro de 2012, grifo nosso)

A meu ver, essas falas do Tata Mutá Imê são muito importantes na medida em que, por um lado, corroborando Parés (2006, p. 319), ele afirma que os rituais expressam fronteiras diacríticas - "eles não sabem fazer festa de candomblé de angola, eles não sabem fazer festa de caboclo" -, por outro lado, contorna a argumentação de Parés e afirma que não são meramente os rituais, as formas de fazer e praticar o candomblé que confundem ou distinguem as fronteiras, mas também o "fundamento" teológico implícito nos rituais e nas formas de fazer, muitas vezes desconhecido nas práticas de um candomblé, digamos aqui, genérico. Observo, a propósito, o cuidado e o uso reticente com que o Tata Mutá Imê usa os adjetivos, os substantivos e convoca verbos para a ação. É recorrente em suas falas, uma pausa e em seguida a pergunta em voz alta: "xô vê se posso falar isso pra você?" Ou então, em um aparente esforço de tradução: "eu não sei exatamente como explicar isso pra você, eu não encontro a palavra".

Em um dos trechos citados acima, por um lado, ao contestar o ato de correlacionar nações distintas, o Tata Mutá Imê, por outro lado, parece admitir a possibilidade de equivalência entre diferentes nações de candomblé no que diz respeito a aspectos teológicos básicos, a saber, qualidades de um orixá, vodu ou nkisi. Porém, Mutá Imê observa que "nkisis, orixá, vodu, caboclo são cultuados de formas diferentes, são fundamentados com elementos diferentes, com línguas diferentes, com danças e cânticos e orações diferentes, não dá para correla- 
cionar". Ou seja, o culto e o manuseio de elementos em rituais equivalentes, muitas vezes, quase sucumbe uma concepção teológica não coincidente, não traduzível de uma nação para outra, marcada no discurso de Mutá Imê pelo substantivo “originalidade", que traduz, nesse caso, palavras não ditas em voz alta, gestos secretos, objetos não nomeados, ordem no uso das coisas ou de cantos. Ou seja, são diferenças sutis (BARTH, 1998) que estabelecem fronteiras intransponíveis, inegociáveis.

Logo, antes de uma nação ter se afirmado e se distinguido de outra em consequência de uma dinâmica competitiva, definida por disputas políticas, de mercado e ideológicas, forjadas ao longo do processo histórico de formação do candomblé, configurado no drible à restrição de livre expressão religiosa durante e depois da escravidão, no drible à demonização de práticas e valores teológicos fundamentais, do preconceito e discriminação raciais (PARES, 2006), é provável que se tenham estabelecido fronteiras como estratégias de solidariedade e cooperação para a tradução de enigmas espirituais e enfrentamentos de dramas definidos pela ordem social e histórica dominante que exigiu a reconfiguração da nação política em nação religiosa (LIMA, 1984). A meu ver, esse argumento se enuncia no modo como Mutá Imê afirma conduzir espiritualmente um provável iniciante: "Olha meu filho, a sua nação é ketu você vai ter que procurar uma casa de ketu pra se iniciar, porque aqui nós somos angola não sabemos, não podemos fazer o seu santo nessa casa". Ou seja, tal como qualquer outro pai ou mãe de santo ketu, jeje ou angola, embora ele saiba "fazer" e conheça o "ritual de feitura", admite não dominar o sentido de cada coisa feita quando a estrutura ritualística está sob uma orientação teológica da qual não adquiriu formação.
Logo, por solidariedade, ética e cooperação reconduz o potencial iniciado.

A partir disso, postulo também uma compreensão diferente no discurso de condenação da "mistura" ou da "impureza" no candomblé por parte de especialistas religiosos com o perfil de Mutá Imê. Ou seja, a mistura, a impureza são condenáveis porque se, por um lado, pode até acertar no "modo de fazer", comete um erro fundante na medida em que um acertado ato ritual ou modo de fazer é incapaz de mobilizar o fundamento teológico e divino que assegura a eficácia da evocação do sagrado e de aspectos ancestrais particulares a um iniciado. Por outro lado, o que muitas vezes, no passado, foi descrito como mera mistura acrítica, esforço de afirmação social, de aquisição de prestígio e poder, pode ter sido uma estratégia de diálogo, fortalecimento espiritual, solidariedade e cooperação inter-religiosa. Além disso, evoca um indício daquilo que Mintz e Price (2003, p. 27-28) definiram como "princípios 'gramaticais' inconscientes que pudessem estar subjacentes à resposta comportamental e fossem capazes de moldá-la" menos em termos de formas socioculturais e mais em termos de valores.

\section{Considerações finais}

Considerando a bibliografia até então citada e a fonte primária encontrada, observo que a presença de negros bantos na Bahia, assim como a anterioridade de suas práticas sagradas afro-centradas é incontestável. Na Bahia, existem registros dos bantos, de sua estrutura e organização religiosa principalmente em regiões agrárias desde o século XVII (SILVEIRA, 2010; FERREIRA, 2016). Entretanto, em autores clássicos bastante citados (RODRIGUES, [1932]1988; RAMOS, [1934]1988; BASTIDE, 1985), esta presença é solapada ou é marcada a inferioridade 
destes em relação aos iorubás, tidos como teologicamente e culturalmente mais evoluídos. Os autores repetem, nesse caso, a argumentação da falta de "pureza", assim como a atribuição de pobreza teológica e ritualística tão diferente em relação à "superior" nação ketu, muito menos influenciada pelo catolicismo que teria assolado, sobremaneira, a nação angola.

Além disso, a referência ao catolicismo e à influência ameríndia são aspectos mencionados para empobrecer o candomblé angola. Desse modo, acredito que já não se trata mais de identificar a presença dos candomblés congo ou angola, ou seja, bantos, na Bahia, mas sim de identificar indícios, o desdobramento de práticas religiosas e a ação social de sujeitos e instituições de orientação banto ao longo da história. Como já nos mostrou Renato da Silveira (2010), desde o século XVII, os negros bantos faziam suas festas, seus batuques, calundus, com a permissividade dos senhores brancos. Ao longo do tempo, em uma suposta tentativa de manter a salvo suas tradições, esses negros conciliaram o culto aos seus deuses e seus festejos ao culto de um panteão de santos mencionados no calendário católico. Aliás, Silveira (2010), mas também Souza (2002), alerta para a similaridade entre rituais sincréticos praticados em território africano, muito antes da chegada dos bantos no Brasil, e rituais sincréticos praticados pelos bantos em território brasileiro assim como para o fato de que em África, os bantos já utilizavam elementos ritualísticos semelhantes aos dos indígenas brasileiros.

Enfim, muitas são as incertezas no que diz respeito à formação do candomblé na Bahia, porém muitas podem ser as surpresas que estão por vir. No que diz respeito ao candomblé angola, por um lado, acredito distante um conhecimento profundo sobre essa tradição, por outro lado, as pesquisas sobre esse tema, até então realizadas, têm revelado pequenos pedaços de um quebracabeça inusitado e fascinante.

\section{Referências}

ALVES, Aristides (org.). Casa dos Olhos do Tempo que fala da Nação Angolão Paquetan. Salvador: Asa Foto, 2010.

BÂ, Hampâté Amadou. A tradição viva. In: KIZERBO, J. História Geral da África, I; metodologia e pré-história da África. São Paulo: UNESCO, 1982. p. 181-218.

BARTH, Fredrik. Grupos étnicos e suas fronteiras. In: POUTIGNAT, Philippe e STREIFF-FENART, Jocelyne. Teorias da Etnicidade. São Paulo: UNESP, 1998. p.185-228.

BASTIDE, Roger. As religiões africanas no Brasil. São Paulo: Livraria Pioneira Editora, 1985.

BASTIDE, Roger. 0 candomblé da Bahia: rito nagô. São Paulo: Companhia das Letras, 2001.

BRAGA, Julio. Oritameji. 0 antropólogo na encruzilhada. Feira de Santana: Universidade Estadual de Feira de Santana, 2000.

CAPONE, Stefania. Entre Iorubas e Bantos: A influência dos estereótipos raciais nos estudos afro-americanos. Antropolítica: Revista Contemporânea de Antropologia e Ciência Política, n. 19, p. 63-90, 2. sem. 2005.

CARNEIRO, Edison [1948]. Candomblés da Bahia. São Paulo: Editora WMF Martins Fontes, 2008.

CARVALHO, José Jorge de. A força da nostalgia: a concepção de tempo histórico dos cultos afro -brasileiros tradicionais. Série Antropologia, Departamento de Antropologia da UnB, Brasília, n. 59, p. 1-36. 1987.

CASTILLO, Lisa Earl. 0 terreiro do Gantois: Redes sociais e etnografia histórica no século XIX. Revista de Hisória, São Paulo, n.176, p. 1-57, 2017. Disponível em http://dx.doi.org/10.11606/ issn.2316-9141.rh.2017.118842. Acesso em 15 de agosto de 2018.

CASTILLO, Lisa Earl e PARÉS, Luis Nicolau. Marcelina da Silva e seu mundo: novos dados para 
uma historiografia do candomblé Ketu. Afro-Ásia, Salvador, Centro de Estudos Afro-Orientais - CEAO/FFCH/UFBA, no 36, p. 103-150, 2007.

CAVIGNAC, Julie. Vozes da tradição: Reflexões preliminares sobre o tratamento do texto da narrativa em Antropologia. Horizontes Antropológicos, Porto Alegre, ano 5, no 12 . p. 245265, dezembro de 1999.

DANTAS, Beatriz Góis. Vovó Nagô e Papai Branco. Usos e Abusos da África no Brasil. Rio de Janeiro: Graal, 1982.

FERREIRA, Elisangela Oliveira. O santo de sua terrra na terra de todos os santos: rituais de calundu na Bahia colonial. Afro-Ásia, Salvador, Centro de Estudos Afro-Orientais - CEAO/ FFCH/UFBA, no 54, p. 111-15, 2016.

FERRETI, Mundicarmo M. R. Mina, uma religião de origem africana. São Luís: Sioge, 1985.

HOBSBAWN, Eric. Introdução: A invenção das tradições. In: HOBSBAWN, Eric \& RANGER, T. (eds.). A invenção das tradições. Rio de Janeiro: Paz e Terra, 1984. p. 9-23.

LIMA,Vivaldo da Costa. "Nações-de-Candomblé". Encontro de nações-de-candomblé. Salvador: Ianamá/Centro de Estudos Afro-Orientais da UFBA/Centro Editorial e Didático da UFBA, 1984. p.19-20.

LIMA, Ari; ALVES, N. L. M. . Vozes negras no Candomblé baiano: Quando a raça importa e quando a raça não importa. Nau Literária, UFRGS, v. 09, p. 01-15, 2013.

MINTZ, Sidney W. e PRICE, Richard. O nascimento da cultura afro-americana. Uma perspectiva antropológica. Rio de Janeiro: Pallas/ Universidade Cândido Mendes, 2003.

MOTT, Luiz. O Calundu-angola de Luzia Pinta (Sabará - 1739). Revista do IAC, v.2, n. 1 e 2, p. 73-82, 1992.

PARÉS, Luis Nicolau. O processo de nagôização no Candomblé baiano. In: SAMPAIO, Gabriela dos Reis, SOUZA, Evergton Sales e BELLINI, Lígia (Orgs.). Formas de Crer. Ensaios de história religiosa do mundo luso-afro-brasileiro, séculos XIV-XXI. Salvador: Currupio/Edufba, 2006. p. 299-330.

PARÉS, Luís Nicolau. A formação do candom- blé. História e ritual da nação jeje na Bahia. Campinas: Editora da Unicamp, 2007.

PIERSON, Donald [1945]. Brancos e Prêtos na Bahia. Estudo de contacto racial. São Paulo: Ed. Nacional (Col. Brasiliana, no 241), 1971.

RAMOS, Arthur [1934]. 0 negro brasileiro. Etnografia religiosa e psicanálise, 2 ed., Recife: FUNDAJ, Editora Massangana, 1988.

REIS, João José. Magia Jeje na Bahia: a invasão do calundu de Pasto de cachoeira, 1785. Revista Brasileira de História, v. 8, no 16 , p. 57-81, mar/ago 1988.

REIS, João José. Domingos Sodré, um sacerdote africano. Escravidão, liberdade e candomblé na Bahia do século XIX. São Paulo: Companhia das Letras, 2008.

RODRIGUES, Raimundo Nina [1932]. Os africanos no Brasil. São Paulo/Brasília: Ed. Nacional/ Ed. Universidade de Brasília, 1988.

RODRIGUES, Raimundo Nina [1900]. 0 animismo fetichista dos negros baianos. Salvador, 2005, P555, (Coleção A/C \Brasil, 2).

SANTOS, Sales Augusto dos. Movimentos negos, educação e ações afirmativas. 2007. 555f. Tese (Doutorado em Sociologia).Departamento de Sociologia, Universidade de Brasília. Brasília, 2007.

SANTOS, Jocélio Teles dos. 0 dono da terra: o caboclo nos candomblés da Bahia. Salvador, Sarah Letras, 1995.

SILVEIRA, Renato. 0 candomblé da Barroquinha: processo de constituição do primeiro terreiro de ketu. Salvador: Maianga, 2006.

SILVEIRA, Renato da. O candomblé-de-Angola na era colonial. In: ALVES, Aristides (org.), Casa dos Olhos do Tempo que fala da Nação Angolão Paquetan. Salvador: Asa Foto, 2010. p. 11-45.

SODRÉ, Muniz. O Terreiro e a Cidade. Petrópolis: Vozes, 1988.

SOUZA, Laura de Mello e. 0 diabo e a terra de Santa Cruz: feitiçaria e religiosidade popular no Brasil colonial. São Paulo: Companhia das Letras, 1986.

SOUZA, Marina de Mello e. Catolicismo negro 
no Brasil: Santos e minkisi, uma reflexão sobre

Recebido em: 01/04/2020

miscigenação cultural. Afro-Ásia, Salvador, Cen-

Aprovado em: 17/05/2020

tro de Estudos Afro-Orientais - CEAO/FFCH/

UFBA, no 28, p. 125-146, 2002.

(c) (i) Esta obra está licenciada com uma Licença Creative Commons Atribuição 4.0 Internacional. 